\title{
Britain and the United States: Two Nations Divided by the Same Language (and Different Language Ideologies)
}

This article examines popular beliefs about language in Britain and the United States within a language ideology framework. With particular reference to Silverstein's discussion of second-order indexicality, it argues that language varieties in Britain and the United States are differently ideologized in such a way as to foreground social class groups in Britain and ethnic groups in the United States. This difference gives rise to characteristically different kinds of national language controversy. American and British images of a spoken standard language are not only quite different but also occupy a pivotal position in their respective ideological systems. In America, a leveled variety is imagined as standard and mainstream, while in Britain an elite classmarked variety is commonly imagined as standard. Each type of standard, while imagined as a neutral reference point, sets up a pattern of structural oppositions that foregrounds and stigmatizes the codes indexing "nonmainstream" groups in the United States and "lower-class" groups in Britain.

$\mathrm{T}$

This article explores different ways in which language forms and varieties are imagined in Britain and the United States as standard, nonstandard, problematic, or inadequate. It attempts to characterize these images within the framework of current work on language ideology and to situate them as elements in somewhat differently structured sociolinguistic landscapes. It is argued that different images of the standard in the two countries form the cornerstones of distinctive language ideologies. 
Subsequently, certain historical events are proposed as critical to an account of why these ideologies have been constructed in particular ways, so as to foreground the language codes that index selected social groups and to render others somewhat less salient.

Debates about standard English and its supposed decline or misuse regularly show up in the newspapers, the television schedules, and everyday encounters of all kinds in both the United States and Britain. Public approbation of standard English and corresponding disapprobation of speakers imagined not to meet appropriate standards are commonplace, as is the belief that there is one and only one correct form of the language. It is this belief which Lippi-Green (1997), following Milroy and Milroy (1998), has described as "the standard language ideology," which in turn provides a rationale for language-based discrimination against marginalized social groups. However, scholars who find themselves in each others' countries are likely to notice that episodes of public hysteria about language characteristically accompanied by widespread anxiety, panic, and irrationality are framed rather differently in Britain and the United States. Although specifying the precise character of these differences is difficult, a long-running controversy in the United States about whether and how English grammar should be taught in schools, with all the ingredients of the "great grammar crusade" discussed by Cameron (1995:78-115), seems somehow implausible. Equally, it is hard to imagine the British press focusing over many years on an English Only movement or on whether British Black English should be used as the medium of initial instruction for native speakers of that dialect, as in the Ebonics debate.

The term moral panic describes a situation "when some social phenomenon or problem is suddenly foregrounded in public discourse and discussed in an obsessive, alarmist manner as if it betokened some imminent catastrophe" (Cameron 1995:82). Such outbreaks have centered in the recent past in Europe and the United States on such issues as immigration, communism, overpopulation, pornography, single mothers on welfare, and pit bull terriers. Cameron identifies the issue of grammar teaching in British schools as a moral panic, and in the United States both the Ebonics debate and the discussion of bilingualism associated with the English Only movement can readily be identified as such. Typically the press plays a crucial role during episodes of moral panic in constructing a particular popularly accepted version of events and resisting alternative accounts. Cameron (1995) and Rickford (1999) assess their contribution, respectively, to the great grammar crusade and the Ebonics debate.

\section{Images of Standard English}

Although public linguistic controversies of this kind are invariably characterized by complaints about the linguistic standards of particular social groups, in both countries the characteristics of the standard language, imagined as essential to good citizenship, are notoriously resistant to precise definition. Popular candidates for the sobriquet of spoken standard are Received Pronunciation in Britain (henceforth RP) and in the United States a 
variety sometimes called "network American" and sometimes "mainstream United States English" (henceforth MUSE). It is plain, however, that RP and MUSE are horses of very different colors. MUSE, discussed in some detail by Lippi-Green (1997:45), is a variety associated not with any particular social group but more broadly with the leveled dialects of the Northern Midwest; that is, dialects where salient locally marked features have been eradicated, so that they are commonly perceived as "colorless" or "characterless" (Wolfram 1991:210). Speakers of such dialects are liable to describe themselves as having "no accent" (Preston 1996a). Referring to systematic work such as Preston's on popular conceptions of the standard, Wolfram and Schilling-Estes have recently pressed this negative characterization of spoken American standard English further, pointing out the apparent irrelevance of regionally marked phonologies to perceptions of (non)standardness:

If native speakers from Michigan, New England, and Arkansas avoid the use of socially stigmatized grammatical structures such as "double negatives" (e.g., They didn't do nothing), different verb agreement patterns (e.g., They's okay) and different irregular verb forms (e.g., She done it), there is a good chance that they will be considered standard English speakers even though they may have distinct regional pronunciations. In this way, informal standard English is defined negatively. In other words, if a person's speech is free of the structures that can be identified as nonstandard, then it is considered standard. [1998:12]

This image of a relatively democratic socially unmarked standard makes the descriptive term mainstream appropriate but also marginalizes nonstandard dialects and speakers by placing them outside the mainstream, an issue we shall return to later.

In Britain, on the other hand, Carter (1999:162) notes that accent (i.e., phonological) variation is crucial in popular perceptions of standard English. The reference point for such perceptions is RP, sometimes described as "Oxford English," "BBC English," or "the Queen's English," a spoken variety saliently marked for class which has never been used by large numbers of speakers. Nor can RP be characterized negatively as can standard American English-on the contrary, its norms were taught to public school boys from about 1870, and it was rigorously codified by Daniel Jones at the beginning of the 20th century (1917). However, Carter supplements these comments on popular perceptions of the standard with a linguist's definition of standard English as "largely a matter of grammar and lexis [that] can be spoken in any accent" (1999:162). This definition runs sharply counter to popular images of the standard (see further below). ${ }^{1}$

Evidently then, the spoken standard is differently imagined in Britain and the United States by both scholars and laypersons. Particularly, popular perceptions involve accent in Britain but not in the United States, where standardness appears to be essentially the avoidance of particular socially marked grammatical and lexical forms. Trask notes a difference in British and American scholarly usage that bears on these characteristic constructions of the standard: 
In Britain dialects are speech varieties differing in vocabulary and grammar, while accents are varieties differing in pronunciation. In the USA the term dialect is commonly understood as including features of pronunciation. This difference reflects the fact that, in the USA, accents are usually closely related to other regional features of usage, while in Britain a regional accent may be largely independent of regional grammar and vocabulary. [1996:166]

The central position of accent in any account of British beliefs about language seems then to be reflected both by popular perceptions and by a scholarly tradition that treats phonology separately from grammar and lexis.

Slippage between British and American uses of the apparently innocuous term standard English apparently extends also to default understandings of what constitutes "nonstandard English." In Britain, unless further specified, this term most frequently refers to urban vernaculars spoken by indigenous working-class British people - effectively class dialects-as in Cheshire and Milroy (1993). However, in the United States the default referent is very likely to be African American English, most famously in Labov's (1972a) polemic "The Logic of Non-Standard English." Thus, nonstandardness in the two countries appears to be primarily, but, of course, not exclusively, associated by scholars with different marginalized social groups.

Preston's recent (1996a) work on laypersons' evaluations of dialects confirms a general absence of consensus on the geographical location of the best-spoken American English. Consistent with the remarks of Wolfram and Schilling-Estes, people find it easier to specify what is not standard than what is; in a sense, the standard of popular perception is what is left behind when all the nonstandard varieties spoken by disparaged persons such as Valley Girls, Hillbillies, Southerners, New Yorkers, African Americans, Asians, Mexican Americans, Cubans, and Puerto Ricans are set aside. Although there is a strong popular belief held also by many professional linguists in a single neutral variety of spoken American English that can be identified as a spoken standard, Preston (1996a:297-298) demonstrates a striking lack of agreement on the locus of such a variety, noting that even influential textbook writers do little more than present their personal beliefs (which are not necessarily shared by all linguists) as linguistic fact. A different scholarly approach is to identify a number of regional standards-a pluralistic concept of the standard that, as Preston notes, is probably not shared by nonlinguists. Certainly there does not exist in the United States a focused, identifiable, and institutionally supported class-indexed accent corresponding to Received Pronunciation in Britain.

Preston investigates popular American perceptions of the standard in a number of ways. He first explores Americans' perceptions of distinctive speech areas in the United States, proceeding then to elicit judgments of the "pleasantness" and "correctness" of varieties thus identified. Correctness judgments are taken to reflect notions of standardness, and pleasantness judgments the affective dimension of reactions to language (1996a:312-317). These correspond to the social status and group solidarity dimensions along which views of language varieties have regularly been shown to vary (Giles 
and Coupland 1991). A very general perception of all Preston's informants is the unique status of the American South as a distinct linguistic and cultural area. Revealingly, one Carolina informant represented linguistic divisions in terms of the Civil War: south of a diagonal line running across the United States from northeast to southwest, "southerners" are to be found; elsewhere reside "damn Yankees." A Michigan informant identified much the same area but labeled it as "southern" with the pejorative description "hillbilly" in parentheses. The Great Lakes area was marked off with the legend "Midwestern English," described parenthetically as "normal."

While Preston's work provides evidence of a widely shared perception of a neutral, leveled variety in the northern Midwest, lack of agreement on a single locus of the most correct variety leads, for example, to southerners identifying the Boston area of New England and Michigan speakers their own region. However, agreement on the least correct variety was much more striking; judges from the South, Michigan, and Indiana all agreed that this might be found in an area of the South (the extent of which varies somewhat between judges) and in New York City. It seems reasonable to suggest that the beliefs reported to Preston are associated with historically deeply rooted divisions between a dichotomized urban, progressive North and an illiterate, rural, conservative, slave-owning South (see Lippi-Green 1997:202 for a discussion of such beliefs and of attitudes to southern speech). It is not entirely clear why New York City but not other American cities should be so negatively evaluated-one possible explanation is its historical status as the first destination of the poorest immigrants. The rationale for this suggestion will shortly become apparent.

The popular characterization of the standard as a variety free from socially or regionally marked features emerging from Preston's work is consistent with evidence of the early emergence of a leveled variety of American English. Read quotes the letter of an English visitor to Maryland, written in 1770:

The colonists are composed of adventurers, not only from every district of Great Britain and Ireland, but from almost every other European government. ... Is it not therefore reasonable to suppose that the English language must be greatly corrupted by such a strange admixture of various nations? The reverse is however true. The language of the immediate descendants of such promiscuous ancestry is perfectly uniform, and unadulterated; nor has it borrowed any provincial, or national accent from its British or foreign parentage. [1980:21, quoted in Chambers 1995:58]

Mencken cites comments made in $\mathbf{1 7 8 1}$ by the Scottish clergyman John Witherspoon, president of Princeton and signatory of the Declaration of Independence. These remarks present a similar picture, drawing also a comparison with usage in the United Kingdom, which suggests less social as well as less regional variation:

The vulgar in America speak much better than the vulgar in Great Britain, for a very obvious reason, viz., that being much more unsettled, and moving frequently from place to place, they are not so liable to local peculiarities either in accent or 
phraseology. There is a greater difference in dialect between one county and another in Britain than there is between one state and another in America. [Mencken 1945:5]

Witherspoon then goes on to suggest that "gentlemen and scholars' in the new Republic were much less careful and correct in their 'public and solemn discourses' than the corresponding dignitaries of the Old Country" (Mencken 1945:5)

While Montgomery's (1996) warnings against an overinterpretation of such evidence of relative homogeneity in early American English are noted, there is little doubt that the 18th-century contact situation gave rise to much greater linguistic uniformity than was (and still is) found in Europe. Baugh (1996:711) and Chambers (1995:58) both comment on linguistic consequences arising from contrasting histories of New World immigrant countries and European countries. Most obviously, since Britain like other European nation-states supported an ancient monarchy and aristocracy, the speech of the educated and the upper class in London was recommended as a social model (Smith 1996:92). ${ }^{2}$ The best known of these recommendations is taken from The Arte of English Poesie (1589, attributed to George Puttenham), in which the aspiring poet is recommended to "take the vsuall speach of the Court, and the shires lying around London within lx miles" (Puttenham 1936:121). In the 17th century, similar statements single out the speech of London or that of the universities of Oxford and Cambridge as the best. Conversely, regional dialects receive adverse comment and are regularly used to characterize naive or rustic speakers. Thus, when Edgar in King Lear takes on the guise of a "base peasant," he switches to Kentish dialect. The association between aristocratic speech and the "best" speech persisted and was unacceptable to early American thinkers. In this context, Heath (1992) discusses the failure of John Adams's attempt to institute an academy on the European model, and the emergence of the ideal of a classless form of the English language known as Federal English, particularly associated with Noah Webster. Contemporary American images of the spoken standard as a socially unmarked leveled variety are consistent with this history.

As is evident from the above discussion, an important difference between Britain and the United States is the complication introduced by the special status of RP, an elite accent used by a tiny percentage of the British population. Yet RP is often described as "standard," particularly in teaching materials for learners of English as a second language. Systematic studies of language attitudes have repeatedly demonstrated its importance in popular constructions of "the best English" (see, for example, Giles and Coupland 1991; Giles and Powesland 1975; Honey 1989:51-78). Several separate investigations suggest that the most consistently stigmatized varieties of English are those of Glasgow, Birmingham, Liverpool (Scouse), and London (Cockney). Most studies, including one carried out in Northern Ireland where RP is seldom heard (Milroy and McClenaghan 1977), show that RP is ranked highest, followed by the relatively standardized varieties used by educated Scottish, Welsh, and Irish speakers; Scottish doctors of medicine appear to 
be evaluated particularly positively. The rural dialects of Northumberland, Cornwall, Devon, or Wiltshire, however impoverished these areas may be, are generally thought to be attractive. Both urban and rural Yorkshire accents are usually positively rated, and viewed as "trustworthy."

An article by Joe Smith that appeared in the London Times Oanuary 2, 1997) 3 shows very clearly the ideological opposition between RP and the urban accents of the industrial north of England, symbolically associated with working-class populations and so heard in "gritty Alan Bleasdale dramas." The social and economic consequences for speakers from industrial cities who do not modify their accents are also clear:

The spirit might be willing, but the flesh is still weak when it comes to not discriminating against people with the sorts of accent you hear in gritty Alan Bleasdale dramas or from Benny at the late Crossroads motel.

The Institute of Personnel and Development came to that insight after questioning recruitment specialists, who confessed that, yes, people with strong regional accents were often discriminated against at work or when applying for jobs. The basic gist is that if you have a Liverpool, Glasgow or Birmingham accent, and you are really keen to get that job, then learn sign language before your interview. Those are the three accents that are seen as "negative" by some employers.

Accent, one London recruitment consultant told the institute, "communicates background, education and birthplace and frankly, some backgrounds are more marketable than others. I would advise anyone with a "redbrick" or industrial accent to upgrade. Politicians and lawyers do it, so why shouldn't others?" Another consultant said: "Let's face it-people with a Scouse accent sound whiny and people with Brummie accents sound stupid." [Smith 1997:6]

This pattern of evaluation of the dialects of major industrial cities as particularly stigmatized and of RP as particularly positively evaluated is very different from that reported by Preston in the United States, where the only urban dialect consistently stigmatized was that of New York City.

Like Preston, Smith draws attention to some confusion in scholars' use of the term standard English. He points out that with reference to the written channel, the term generally refers to "the fixity of spelling, lexicon and grammar which derives from the work of the prescriptivist writers of the eighteenth century. To use standard English is to signal competence in a set of well-established rules endorsed by a normative education system" (1996:65). With respect to the spoken channel the situation is much less clear, since in this context standard language becomes a more complex and socially loaded term. In Britain, Smith notes, many view the spoken standard as a "prestigious system of grammar and lexis" that can, but need not, be realized with a class-specific RP accent and can be spoken with "a Scottish, Welsh, American, Australian or Yorkshire accent" (Smith 1996:65; see also Trudgill 1999 for an elaboration of this view). Smith points out that others, however, refer to standard English spoken with an RP accent as the standand language. Thus, RP is sometimes in practice treated as a reference accent, in response to its status as a class accent. What these differences between British and the American constructs amount to is an image of a leveled type of spoken standard in the United States, as opposed to a British standand 
constructed (however indirectly and inexactly) with reference to a particular socially marked linguistic model.

Let us conclude this review of images of standard English with a brief discussion of the popular belief system described by Milroy and Milroy (1998) and Lippi-Green (1997) as the standard language ideology. Its chief characteristic is the belief that there is one and only one correct spoken form of the language, modeled on a single correct written form. That this form is resistant to definition is beside the point. Although no clear distinction is usually made between spoken and written language, the standard language ideology generally sees optional variation in either channel as an undesirable deviation from a uniquely correct form. Such a belief is widely and tenaciously held by persons of all ages, intellectual levels, political persuasions, and social statuses in the face of ample evidence derived from everyday experience that language variation is both necessary and functional. Furthermore, insofar as it is implicated in language contact ("foreign accents") and processes of linguistic evolution (as are many stigmatized, nonstandard variants at all linguistic levels), patterned variation is necessarily found in all speech communities. Yet the standard ideology holds that far from being a morally neutral fact of social life, language change equates with language decay, and variation with "bad" or "inadequate" language. Metonymic shift provides the slippage for such negative judgments to be expressed in terms of undesirable moral, intellectual, or social attributes of groups of speakers (but see also the discussion below of the semiotic process of iconicity). After all, sloppy or lazy speech must be produced by sloppy or lazy speakers, dim-witted speech of the kind characterized by glottal stops is inevitably produced by dim-witted speakers, and the speech of the gutter is also the speech of people who habitually live in the proximity of the gutter. Examples of such value-laden and often intemperately articulated beliefs are not difficult to find. Resistant to change or rational reflection, they tend to be presented by those who hold them, including the stigmatized speakers themselves, as "common sense." This expression generally denotes an unanalyzed ideological belief system. Thus, when we hear proclamations by Republican senators that it is common sense that English should be the only language used in the official documents of the American federal government, or by British Conservative cabinet ministers that standards of English will improve since common sense is back in fashion, we can be sure that they are exploiting unanalyzed ideologies. Rational debate is avoided by an implication that it is superfluous (Milroy and Milroy 1998:135).

\section{Language Ideology}

The brief account of the standard language ideology set out above does little more than describe its key components, which are essentially supportive of a form of the language imagined as "standard," and adversely critical of the speech of disfavored social groups. Wooland and Schieffelin have succinctly formulated the important issues for a systematic study of language ideology, pointing out the limitations of accounts that merely note 
that its effects are to use language as a cover for discriminatory practices that cannot be overtly implemented:

Symbolic revalorization often makes discrimination on linguistic grounds publicly acceptable, whereas corresponding ethnic or racial discrimination is not. However, simply asserting that struggles about language are really about racism does not constitute analysis. Such a tearing aside of the curtain of mystification in a "Wizard of $\mathrm{Oz}$ theory of ideology" . . . begs the question of how and why language comes to stand for social groups in a manner which is both comprehensible and acceptable.

[1994:62, emphasis added]

Scholars have addressed the central question posed by Woolard and Schieffelin in a number of ways, usually with an initial assumption that language ideologies mediate in a significant manner between macrolevel social structures and particular forms of talk. This assumption allows language ideology to be analyzed systematically as part of a sociolinguistic account of language variation, rather than being dismissed as an irrelevant, ill-informed, and prejudiced response to disfavored social groups. A useful starting point is provided by Rumsey's definition: "shared bodies of commonsense notions about the nature of language in the world" (1990:346).

Following his major investigation of lay attitudes to varieties of American English (1996), Preston has more recently moved toward an account of popular theories of language and language variation within a broad language ideology framework. He remarks that beliefs about language correspond to D'Andrade's (1987) notion of a "cultural model"-a cognitive schema shared by a social group (Niedzielski and Preston 1999). According to D'Andrade, it is this very intersubjectivity that allows interpretations of the world on the basis of such models to be treated as if they were obvious. Furthermore, such sharing entails also that information related to the model does not need to be made explicit. Hence the resistance of linguistic ideologies to rational explanation or argument, regardless of the intellectual acuity of those who hold them. ${ }^{4}$ However, such an analysis still begs the question of how these intersubjective schemata emerge in the first place. Lippi-Green (1997) views them as subordination strategies, designed to enforce the belief systems of a majority that imagines itself as "mainstream" and to marginalize minorities. The subordination process is carried out at all levels of activity by agencies such as the workplace, the information and entertainment industries, and the educational system. Much of Lippi-Green's book describes the manner in which this subordination is accomplished, both in institutional contexts and in interpersonal encounters.

A different strand of research, central to an understanding of how ideologies emerge and function as workable models for social actors, involves analysis of the semiotic processes that give them their significance. Silverstein $(1992,1995)$ views ideology as a system for making sense of the indexicality inherent in language. Uncontroversially, languages and language forms index speakers' social identities fairly reliably in Britain, the United States, and elsewhere. However, indexicality can usefully be ranked into different orders of generality. For Silverstein, first-order indexicality entails 
the association of a linguistic form with some socially meaningful category-such as female, black, Asian, Spanish, working class, aristocratic. Second-order indexicality, however, he treats as a metapragmatic concept, involving the noticing (overt or covert), discussion, and rationalization of basic first-order indexicality. Since linguistic varieties index social class and ethnicity in both countries, where Britain and the United States differ is likely to be not in first-order indexical processes but in second-order processes whereby different varieties are noticed as significant, communities differently typify and ideologize the kind of people who speak such foregrounded varieties, and different relationships are constructed between social groups. An analysis in terms of Silverstein's concept of second-order indexicality thus provides for relative prominence in cultural models of particular social groups and the recession of others as first-order indexicalities are rationalized in different ways.

Reactions of participants to forms of the kind discussed by Labov (1972b), indicating linguistic insecurity, stylistic shifting, and hypercorrect behavior, are also instantiations of second-order indexicality. They arise from awareness of the hegemonic nature of the standard and its social construction by scholars and lay participants alike as a neutral reference point for all variability. Linguistic stereotypes, distinguished by Labov from indicators and markers, show the effects of ideological construction particularly clearly. The language analyses of scholars are imbued with ideological significance, since there is no absolutely neutral way of analyzing language variation. We have already noticed, for example, the contrast between British and American scholarly conceptions of dialects and standard languages. Milroy (in press) discusses the way in which distinctive national language ideologies can be seen to shape the research agendas of sociolinguists who engage in applied work addressing issues of language-based discrimination. Walters (1996) discusses effects of the assumption of the neutral standard and the inconsistencies that become evident when African American students are introduced to elementary linguistic textbooks.

Since they often purport to explain and rationalize the source and significance of linguistic differences, second-order indexical processes have the effect of distorting the relationship between the index (i.e., the linguistic form) and the social group indexed. This is because "participants" ideologies about language locate linguistic phenomena as part of, and as evidence for, what they believe to be systematic behavioral, aesthetic, affective and moral contrasts among the social groups indexed" (Irvine and Gal 1994:4). Hence we find beliefs about the superiority of the standard, the impoverished character of working-class or ethnic dialects, the superiority of English over other languages. Irvine and Gal (1994:1) suggest that ideologies emerge as a consequence of attempts by individuals to formulate understandings of linguistic variation that can then be mapped onto significant people, events, and activities. This is an important observation, as events, people, and activities viewed as significant will vary between communities. I shall attempt to demonstrate shortly that historical accounts are helpful in understanding why the people, events, and activities that come to be seen as significant differ in Britain and in the United States. 
Irvine and Gal identify a number of semiotic processes by which ideologies frame understandings of linguistic differences in such a way as to identify and account for the relationship between linguistic variation and particular people (1994:4). Of these processes, iconicity and erasure are most important for present purposes. Iconicity (more recently labeled iconization) changes the relationship between an indexical linguistic form and a social group, with the effect that it appears to be an iconic representation of that group and is imbued with the same social characteristics (laziness, sloppiness, immorality, elegance, intelligence). An excellent example may be found in Rickford's account of the vicious jokes and parodies that appeared on the Internet in the wake of the Ebonics debate, following a proposal by the school board of Oakland, California, to allow African American English (AAE) to be recognized as a valid language distinct from English and to be used as a medium of initial instruction for AAE speakers. After describing Internet responses, Rickford comments:

Language was no longer at issue; "Ebonics" had become a proxy for AfricanAmericans, and the most racist stereotypes were being promulgated. This cruel humor might remind us, however, that behind peoples' expressed attitudes to vernacular varieties, there are often deep-seated social and political fears and prejudices about their speakers. If we don't take the "socio" part of sociolinguistics seriously, we won't be prepared to understand or respond to such attitudeseffectively. [1999:272]

Erasure works rather differently, simplifying the sociolinguistic landscape to render some part of it invisible. This allows facts that are inconsistent with the schema to go unnoticed. Thus, for example, Niedzielski and Preston (1999:302-324) note that the language of stigmatized groups in the United States is subject to folk caricature and adverse comment on the basis of minute variations from a standard. For example, in (1) below, participants treat as iconic the phonological form [akst] for the lexical item asked, uttered by an African American speaker. However, regional variations that do not index salient social differences, such as the alternation in north Midland dialects between gerund and participle, pass unnoticed: ("my clothes need washing/need washed"). Similarly, although his subjects regularly parody such varieties as African American English and southern American English, white middle-class English appears to be imagined as homogeneous and thus not available for caricature (Preston 1996b).

Woolard (1992) reviews several perspectives from which scholars have approached language ideology. It is enough to comment here that it may be viewed fairly neutrally as a set of shared cultural conceptions, or rather less neutrally as an indispensable tool for the exercise and legitimation of power. Since we are dealing with different ways in which individuals in two large nations imagine themselves and model the social groups that seem most significant, pernicious, or threatening, this second perspective will also be important in our analysis. As Rumsey has observed, it is critical to ask whose interests are served by an ideology taking the form it does (1990:346). As well as applying an ideological analysis of the second type 
to the operation of American institutions, Lippi-Green (1997) reviews a large body of relevant work, including important contributions by Gramsci, Foucault, and Eagleton. This work treats ideology as a procedure developed by social and political institutions to subordinate and marginalize disfavored social groups. As exemplified by Lippi-Green's own analysis, the chief goal is to specify operationally (rather than at a semiotic level) the processes that allow, without public protest or debate, and often with their own acquiescence, the language of the least politically and economically powerful social groups to be stigmatized as "bad," "incomprehensible," "sloppy," and worse. With this goal in mind, Eagleton memorably defines the study of ideology as "an enquiry into the ways in which people may come to invest in their own unhappiness" (1991:xiii-xiv).

An extensive and now wellestablished body of research into group behaviors within a social psychological framework has shown that attitudes to language codes and their different values manifest relationships between language and group identities and conflicts (see Lambert 1960 for an influential methodological model, and Giles and Coupland 1991 for an overview). More recent work in the language ideology tradition has reframed these well-documented attitudes of groups and individuals as a socially derived consensus manufactured by a range of agencies and enforced in such arenas as education and employment (Herman and Chomsky 1988). Woolard explains the "visceral" nature of language attitudes evident in (1) and (2) below in terms of this micro-macro link:

Shared social values, or perhaps more correctly, evaluations, are key links between macrosocial changes and the way people talk.... In most peoples' experience, reactions to certain styles of speech, particularly stigmatized ones, can be visceral, and may conflict with more consciously and deliberately held valuations of the people we hear. Even in less dramatic moments, we make surprisingly definite judgments about people's intellectual and moral qualities on the basis of the way they "sound." ... These associative judgments are part of what Bourdieu calls our "habitus," in the sense that they are incorporated or literally embodied in our aural perceptions. [1989:89]

Heller (1995) illustrates this link between macrolevel change and forms of talk by showing how the macrolevel political divisions between anglophones and francophones in Quebec are faithfully reproduced both in patterns of small group divisions and in code-switching practices in individual face-to-face interactions. Thus, interactional behavior and national language policies are viewed within a language ideology framework as a unified object of inquiry.

Language ideologies are instantiated in everyday discourses of all kinds, such as in the two examples that follow, one an article taken from a popular British women's magazine and the other a transcript from an American television program. While each gives a sense of the somewhat different flavors of contemporary British and American language ideologies, both show how language ideology stigmatizes and marginalizes particular social groups. However, the social groups selected differ in the British and American examples in ways that I hope later to demonstrate are fairly typical of 
these nations' differently constructed ideologies. Two somewhat different images of a linguistic standard are also displayed, consistent with the account given above; only the British example focuses on accent, while the American example focuses on lexis and on language choice (viz., Spanish versus English).

The British example, entitled "Can Your Accent Blight Your Life?", describes the experiences of Helen, a Manchester woman who moved to London in search of employment:

"In the arts where no one has a regional accent [i.e., RP is the expected norm] ... my CV was good enough to get me interviews, but ... as soon as they heard me speak ... I wasn't taken seriously." ... And when Helen finally landed a job with a community theatre project in Islington, North London, she was told she'd only been selected because the area would benefit from a "common touch." Helen encounters similar reactions in casual interpersonal encounters: "People can't see further than my voice and assume I'm aggressive and common. They think I should own pigeons and have an outside toilet." [Daubney 1996:23]

The American example comprises two extracts taken from a transcript of a 1987 screening of The Oprah Winfrey Show called "Standard and Black English," ${ }^{15}$ where both studio audience and telephone callers contributed on the topic of African American English:

1

Second Caller.

Winfrey:

Second Caller:

Winfrey:

Second Caller:

2

Audience Member \#9: The problem seems to be that everybody tries to

Winfrey:

Audience Member "10:

Winfrey:

Audience Member \#9: push something down your throat by arrogance. That's not the way to get something done. You could speak your own language, you could have your own way, but don't force someone else to have to suffer and listen to it.

\section{$\mathrm{Hi}$, Oprah?}

Yes

I guess what I'd like to say is that what makes me feel that blacks tend to be ignorant is that they fail to see that the word is spelled A-S-K, not A-X. And when they say "aksed," it gives the sentence an entirely different meaning. And this is what I feel holds blacks back.

Why does it give it a different meaning if you know that's what they're saying?

But you don't always know that's what they are saying.

You say what?

Well I'm an accountant and-

Well, wait, wait, let me get back to you. What is causing you to suffer?

Well I think there is a certain way of speaking that has been considered the acceptable way of speaking. And because of that this is the type of language you speak when you're out in the world. If you want to 
speak Spanish at home that's fine. If you want to speak black with your friends that's fine. But don't insult someone else's ears by making them listen to it.

Some of these comments are presented as tolerant of an "appropriate" variability, such as ninth audience member's second contribution in response to a question from Oprah Winfrey who, herself African American, views African American Vernacular English as inappropriate in academic, professional, and mixed-race contexts (but see Fairclough 1992 on the ideologized nature of "appropriateness"). However, it is equally clear that for the most part the contributions in (1) and (2) are targeted on particular racial or ethnic groups and the attitudes reported in Bella on imagined workingclass speakers associated particularly with large northern industrial cities, of which Manchester is one. So much is clear from the expressions "common touch," "aggressive and common," and the reference to pigeons and outside toilets that stereotypically characterize northern English working-class lifestyles. The semiotic process of iconicity/iconization described by Irvine and Gal accounts for the strong gut reactions evidenced here; Helen experiences difficulty when people hear her voice because they attribute to that voice undesirable qualities imagined to be characteristic of working-class speakers, such as aggressiveness and commonness. Similarly, black speakers are ignorant because the phonological form [akst] for the lexical item asked is incorrect, and for that reason they are economically unsuccessful. The linguistic form itself constitutes the social problem. Similarly, the choice of Spanish by Spanish speakers is not noted as a neutral fact but as an aggressive act. While indexing Spanish ethnicity, it becomes imbued with qualities attributed to the group. In a more general way, the process of erasure accounts for the salience of some social groups and the invisibility of others in ideologically imbued comment of this kind. Lippi-Green (1997:134) has discussed the manner in which American language and culture is publicly presented as homogeneous, despite abundant evidence of bilingualism and cultural heterogeneity. As Irvine and Gal remark, an erased element that at some point becomes particularly prominent may be seen as a threat. Spanish bilingualism may be seen as representing just such an erased element.

\section{Race, Ethnicity, Class, and Language Ideologies}

It was noted that the metapragmatic comments in the Bella extract stigmatize groups defined on the basis of social class and those in (1) and (2) particular ethnic groups. Before presenting further evidence of the somewhat different national ideologies instantiated in these examples, I comment on the understanding of the terms class, ethnicity, and race embodied in this article, which is in accordance with that presented in Giddens's discussion of structures of inequality (1989:205-273). Class is distinguished there as one of four major types of stratification systems that promote inequality in society. While the other three (slavery, caste, and estates) depend on institutionally sanctioned inequalities; class divisions are not officially recognized. Since an individual's class position is to some extent achieved, stratification by class is accompanied by varying degrees of mobility. Where mobility is 
greater (as in the New World), class consciousness, which is generally strong in the West, is likely to be less salient than in the Old World, where it is further reinforced by inherited rank systems. In much of the West a division of the population into upper, middle, and lower classes is popularly accepted as a reasonable description of the stratification system. The major distinction drawn by Giddens between consensus and conflict theories of class (discussed in Milroy and Milroy 1992) is not relevant here.

Ethnic groups are formed by persons who share, or believe they share, common cultural characteristics that are wholly learned, typically very early in life. These generally involve a sense of place and of a common history and destiny, a shared religion and culture, a shared language or languages, a shared set of communicative conventions, and shared cultural models. In practice, most discussions of ethnicity involve minority groups whose members are discriminated against by the majority population. Like class boundaries, ethnic boundaries are to varying degrees permeable.

Race is closely associated with ethnicity, in that it refers to physical characteristics that are treated as ethnically significant-most commonly skin color-while racism refers to the false attribution of undesirable inherited characteristics to persons of a particular physical appearance. Giddens points out that the persistently problematic character of race relations in the United States can best be comprehended within a historical context, since from the earliest days the racist views of European colonists were more extreme with respect to the Africans who had been brought to the Americas as slaves than with respect to other non-Europeans, including Native Americans. Linking the rise of racism in the New World with slavery and the early period of colonialism, he points out that "ever since then racial conflicts and divisions have tended to have pride of place in ethnic conflicts as a whole. In particular, racist views separating 'whites' from 'blacks' became central in European attitudes" (Giddens 1989:254). Cornel West vividly characterizes the way in which this outcome erases other kinds of social divisions in the United States: "Without the presence of black people in America, European Americans would not be 'white'-they would be only Irish, Italians, Poles, Welsh and others engaged in class, ethnic and gender struggles over resources and identity" (1993, cited in Proulx 1997:10).

Crucially, the focus of the argument in this article is not on social categories of race, ethnicity, and class per se, nor on actual discriminatory practices, nor on the relative structural positions of class and ethnic groups in Britain and the United States (although these are likely to differ in interesting ways). Rather, it is concerned with national language ideologies-that is, the construction of comparable but distinctive cultural models as a result of the different ways those language forms that index particular social groups are discussed, typified, rationalized, and imagined. Nor do I suggest, as is sometimes (ideologically) claimed, that Britain is free of racial discrimination and the United States of class prejudice (language based or otherwise). Rather, I argue that Silverstein's second-order indexical processes operate differently in the two countries, so that language varieties indexing race and ethnicity come to the fore in American ideologies, while those that index class recede. The converse happens in Britain, with the effect that the 
most visceral reactions are typically reserved there for varieties indexing class, while in the United States such reactions are more likely to be elicited by varieties that primarily index race and ethnicity, as illustrated respectively by the Bella and Winfrey show extracts presented above. My overall goal is to explore in some depth these different ideological structures and the significant events, persons, and activities that lead to particular ideologies taking the form they do.

The two samples of ideologically imbued discourse presented so far have been drawn from popular print and television journalism. However, acceptance of the web of common sense assumptions that make up cultural models is far wider ranging than these examples suggest, transcending divisions of ethnicity, class, and gender and permeating institutional planning and policy. The pervasiveness of ideological belief systems is particularly visible in public language controversies; for example, as Wolfram points out, the Ebonics controversy has shown political opponents such as the conservative Rush Limbaugh and the progressive Jesse Jackson to agree in their public condemnation of the Oakland School Board's initiative (1999:363). Such agreement across barriers of political position dramatically illustrates the capacity of the shared cognitive schemata embodied in language ideologies to be treated as if they were obvious and not in need of explication. Because of their pervasiveness and relative stability both in public policy and in discourse that is not overtly political, I do not attempt in the following discussion systematically to distinguish these different contexts. However, I shall try to show that while the ideological contrasts suggested by the Bella and Winfrey show extracts are evident in many domains other than popular print and television journalism, many kinds of context, they are also associated with deep-rooted national preoccupations and anxieties. Consider first some evidence from the United States.

Public disparagement of African American English is common in discourses addressed to many different audiences. The following comments on salient AAE morphological forms (which, contrary to the author's claims, are well attested in the history of English) are taken from a best-selling paperback book written by a journalist with some intellectual pretensions purporting to address a cultivated readership. The work embodies throughout a great intolerance of variability at all levels of language and so constitutes a strong and influential statement of the standard language ideology. Yet the same process of iconization of AAE language forms is evident here as in the on-line comments of Oprah Winfrey's audience members or in the Internet contributions to the Ebonics debate described by Rickford (1999).

As for "I be," "you be," "he be," and so forth, which should give us all the heebie-jeebies, these may indeed be comprehensible, but they go against all accepted classical and modern grammars and are the product not of a language with roots in history but of ignorance of how language works (Simon 1980:165). I comment later on historical events that have helped to shape a language ideology where AAE is prominently foregrounded.

An audience contribution in (2) above suggests that the Spanish language is also viewed with disfavor. Lippi-Green (1997) provides in several places thorough discussions of such negative attitudes to Spanish and Spanish- 
accented English in the United States in the context of negative attitudes to languages other than English and to "foreign accents" more generally. Such ideologies are evident in the domain of public policy also, both underpinning and being supported by the fierce and long-standing political conflict associated with the English Language Amendment (ELA). The basic goal of the ELA, first proposed by Senator Hayakawa (R-California) in 1981, is to make English a de jure rather than a de facto national language. McArthur (1986) has analyzed widely shared images of specifically Hispanic immigration and culture as central to this Anglocentric movement. He notes that Spanish speakers continue to have a significant presence in the Americas and to immigrate to the United States in considerable numbers, sometimes across porous national borders. He compares fears that

Anglo-America could be swamped by Hispanic-Americans to the fear that French America (Quebec) could be swamped by English America (Canada plus the United States).... The Hispanic issue is complicated by the fact that Latin America is largely part of the "Third World" while many Americans see themselves as the great bastion of the never-stated "First World." It happens that Spanish is the language of the masses perceived variously as illiterate, impoverished, dirty, backward, criminally inclined, residually Roman Catholic, prone to Communist infiltration, dark complexioned, and now pushing cocaine and marijuana north for all they are worth. [1986:91]

Thus, although the political purpose of the ELA might be to inhibit further immigration by Spanish speakers (as suggested by Bourhis and Marshall 1999), it embodies a characteristic national language ideology, visible also in the informal, on-line discourse exemplified in (2) above. This ideology foregrounds Spanish speakers (along with African Americans) particularly saliently, often erasing other social groups.

McArthur's view of the ELA lobbying effort as essentially an antiHispanic, anti-immigrant coalition is widely shared (see, for example, Castro 1992:182). However, it is hostile not only to other bilingual groups but to official educational provision for the needs of AAE-speaking children, as shown by its interventions in the Ebonics debate, which became particularly heated in January 1997. The ELA lobby has an extremely high public profile, characteristically eliciting and expressing the strong visceral reactions characteristic of unanalyzed language ideologies. Consider Cárdenas's comments on responses to arguments for initial instruction in Spanish for monolingual first grade children:

The emotional responses to bilingual education sometimes get so intense that they defy all reason. On two occasions I have read articles in which the writers object to the use of the phrase "English as a second language." The argument presented in both cases was that English is the greatest language on earth and therefore second to none. How does one argue with such an individual that the word "second" refers to chronological order? [1992:349-350]

Fishman (1992) notes the prominence of language policy as an internal issue for the first time in American history in the years following the 
emergence of the ELA lobby. Commenting on the three to one majority in favor of the English Language Amendment passed in California's state legislature in November 1986, he identifies the English Only movement as uniquely and characteristically American:

No similar legislative effort to redress the internal insults to English, real or imaginary, have surfaced in any other core countries of English, such as England, Australia or New Zealand, all of which have substantial non-English-mother-tongue populations of their own. The general view toward non-English languages in governmental use in these countries is quite benevolent and even supportive in ways undreamt of here. [1992:166]

While Fishman's view of institutional benevolence toward linguistic minorities in English-speaking countries other than the United States is optimistic (consider, for example, evidence presented in Roberts et al. 1992), it is certainly true in Britain at least that minority language issues seldom emerge either in popular or political discourse. London Jamaican, the ethnically marked variety that might be thought to correspond to AAE in the United States, is indeed negatively evaluated but does not occupy the most disparaged position (Honey 1989:59). The following comment of a British child of Caribbean origin, writing in 1981, appears to equate London Jamaican and Cockney as nonstandard varieties, providing no evidence of the sharp dichotomy between "black talk" and "white talk" characteristic of United States discourse on AAE: "I feel that there is nothing wrong in speaking Creole as there is nothing wrong in speaking Cockney, but I feel that when you go for an interview or you are speaking to someone important you should try to speak as close as possible to Standard English" (Sebba 1993:14).

In Britain, it is the legitimacy and acceptability of the indigenous nonstandard dialects of industrial cities that typically elicits discourse comparable to American comments on AAE and Spanish. Such discourse generally alludes directly or indirectly to social class or social mobility, foregrounding class-marked codes. Cameron (1995:96) comments on the recurrent representation in Britain of working-class speakers as a threat and the preoccupation with "correct English" as a counter to that threat. This preoccupation underlies not only media comment on language issues but British government educational policy during the 1980 s and early 1990 s-and indeed earlier, as is shown by the language of the officially commissioned Newbolt Report on English teaching (1921). Here, difficulties experienced by elementary school teachers are described as "a fight against the powerful influences of evil habits of speech contracted in home and street. The teachers' struggle is not with ignorance, but with a perverted power" (Newbolt 1921:59). As Cameron points out, the teaching of correct English is persistently presented in Britain "as part of a more general 'struggle' against dark social forces, and specifically as a means to counter the anarchy of the (working-class) home and street" (1995:96). She analyzes here a discourse that embodies fears and identifies salient and threatening social groups in a manner 
parallel to McArthur's analysis of reactions to Spanish speakers in the United States.

The same concern with class quite directly underpins public reactions to so-called Estuary English, a leveled variety currently spreading both socially and geographically as a reflex of Britain's changing mobility patterns and class structure (see Dorling 1995, esp. ch. 6). The following newspaper headlines are drawn from a wide selection of comparable comments on a topic that received particularly extensive media exposure between 1994 and 1996, following reports of research on dialect leveling in the southeastern English town of Milton Keynes (as discussed by Kerswill 1996):

3

Between Cockney and the Queen: "Estuary English" describes the speech of a growing number of Britons. Poised between RP and Bow Bells it minds its "p's" and "q's" but drops its "t's." [Coggle 1993:21]

4

Britain's crumbling ruling class is losing the accent of authority ... the upper-class young already talk Estuary English, the cockneyfied accent of the South-east. [Ascherson 1994]

5

Pity the young who converse only in Oik. [Tory 1994:24]

Tory proceeds to distinguish between the urban, leveled dialect of Milton Keynes and older, more "respectable" dialects:

According to Reading University, this repellent sub-world speech is originating in Milton Keynes. ... All sorts gather there from every corner of the land, most of them making a career out of soldering on microchips and have produced, from dozens of once respectable dialects, a hellish, slowspreading universal yobtongue. [Tory 1994:24]

This ideologized contrast between legitimate traditional dialects and more recent degenerate urban dialects emerges quite regularly in British discourse. For example, Keith Waterhouse draws a distinction similar to Tory's between the urban dialect of Milton Keynes ("slack-mouthed patois") and traditional regional dialects:

Most regional accents-Northern, Scottish, Welsh, West Country, East Anglianare attractive enough, (although I'm afraid I can see no case for Brummagem [the urban dialect of Birmingham]). They have evolved from local conditions and local history-the Yorkshire truncated $t^{\prime}$ for the, for example, comes out of the mills where you had to speak loudly and succinctly to be heard above the clatter of the looms. [1994:10]

Twenty years earlier, in a systematic study of language variation and language attitudes in Glasgow, Macaulay (1977) reported that teachers and employers regularly drew this genuine dialect/degenerate speech distinction. When the distinction emerges, genuine dialects are usually associated 
with rural areas or small towns and degenerate speech with industrial cities. Such a dichotomy is consistent with the recurrently expressed fears of the dark forces of home and street alluded to by Cameron, imagined as a property of specifically urban working-class culture. As might be expected, given the very different sets of oppositions constitutive of the American ideological system, no comparable city/country opposition is reported in major accounts of attitudes to language in the United States such as those of Lippi-Green (1997) or Preston (1996).

\section{A Historical Perspective on Language Ideologies}

Irvine and Gal's (1994) account of the semiotic process of erasure begs the question of why in a given case particular elements are erased and others foregrounded. In fact, as a comparison of British and American ideas of the standard language shows, historical contingency appears powerfully to influence contemporary ideological salience of particular elements. As noted earlier, Giddens (1990) highlighted the relevance of the early colonial period in formulating an understanding of attitudes to race in the New World. By the same token, entrenched class systems of Old World states such as Britain affect the way society is imagined and hence the form taken by national language ideologies. In this section I focus more specifically on events and images from the 19th and early 20th centuries that seem particularly relevant to the formulation of contemporary language ideologies.

\section{Britain: Some Historical Issues}

Crowley (1989) discusses in depth the 19th- and early-20th-century background to contemporary British language ideology, where several separate developments can be distinguished. Most importantly, massive social and economic changes following the Industrial Revolution (in England conventionally dated 1760-1851; see Corfield 1991:2) led to the redefinition of regional dialects as class dialects, following population shifts from the countryside to the cities. This redefinition appears to underlie the characteristically British dichotomy between genuine (rural) dialects and degenerate (urban) speech.

Mugglestone (1995) documents in detail the emergence specifically of accent as an index of class during the 19th century, a period of great social mobility. A number of prominent phonological variables (such as $h$-dropping; the alternation between in' and ing) became redefined during this century as salient class markers, and some familiar ideologically imbued expressions came into use (the "educated accent," "talking proper," the "public school accent," "talking without an accent"). Citing the prominent 19 th-century novelist and social commentator George Gissing, Mugglestone comments,

Like class itself, accent was, in effect, to become a major national obsession over this time. "Classes are getting mixed, confused ... we are so conscious of the process that we talk of class distinctions more than anything else-talk and think of them incessantly," as Gissing stressed in Borm in Exile. Since it was accent which 
popularly came to be conceived as a prime marker of class distinction, this habit was, in many ways, thus almost guaranteed to ensure its prominence in the public mind. [1995:6]

Consistent with the developments described by Mugglestone, Oliphant uses the discourse of class rather than region or rusticity to criticize $h$-dropping: "Those whom we call 'self-made men' are much given to this hideous barbarism. ... Few things will the English youth find in after-life more profitable than the right use of the aforesaid letter" (Oliphant 1873:226, cited in Milroy and Milroy 1998:2). In the late 19th century, RP, already noted as crucial to contemporary British images of the standard, took its place as an important element in the British sociolinguistic landscape. Honey (1989:12-37) notes that no elite class accent was used by those who had received a privileged education before 1870; for example, Prime Minister Gladstone, who was a student at Eton in the 1820s, retained the phonological system of his native Liverpool throughout his life. ${ }^{6}$ However, from 1870 onward, the English public school system (i.e., a network of elite private schools) expanded greatly to provide a high-prestige boarding school education that supplied valuable social credentials. Such an education, apparently regardless of intellectual attainment, opened for pupils the doors to those ancient guardians of the standard language, the universities of Oxford and Cambridge, and to careers such as the Anglican clergy, an Army commission, colonial administration, and teaching. Not only was the accent explicitly taught, but boys entering a school such as Eton or Harrow with regional accents were shamed into conformity. By the end of the 19th century, according to Honey, an RP accent proclaimed either that its user was a public school man or that he had gone to some trouble to acquire an accent that signaled his adherence to the values of the elite for whom it constituted important social capital.

It is not difficult to find evidence of the social and economic importance of RP well into this century. For example, accent was the most important requirement for an Army officer in World War I until a shortage of officers forced the Army to promote men with regional accents. These were the "temporary gentlemen" referred to by the novelist Pat Barker's public school educated officer Charles Manning as he listened to a young officer from Salford, near Manchester: "Noting Prior's flattened vowels ... the amazing thing was how persistent one's awareness of the class distinction was ... the mind seemed capable of making these minute social assessments in almost any circumstances" (Barker 1993:240-241). Certainly the structural position of RP is not paralleled by any single class-specific accent of English in the United States, and at this period RP operated as a fixed standard rather than a norm toward which speakers tended. By this is meant that RP was effectively a "fixed collection of prescribed rules, from which any deviation at all is forbidden" (Smith 1996:66). Confident control of RP was an advantage (and often a necessity) in a wide range of professions, indexing not only class but a sound educational background. The accent requirement diffused downward in employment domains with a "linguistic market" orientation, such as teaching and secretarial work. The writings of Henry Cecil 
Wyld, Merton Professor of English at Oxford, are imbued with the ideology that continued to link accent and class particularly strongly in the first half of the 20th century. Wyld argues thus for the intrinsic aesthetic merit of RP (his term was $R S=$ Received Standard):

If it were possible to compare systematically every vowel sound in RS with the corresponding sound in a number of provincial and other dialects, assuming that the comparison could be made, as is only fair, between speakers who possessed equal qualities of voice and the knowledge how to use it, I believe no unbiased listener would hesitate in preferring RS as the most pleasing and sonorous form, and the best suited to the medium of poetry and oratory. [1934:605]

Wyld defines the social domain of RS extremely narrowly as follows:

If I were asked among what class the "best" English is most consistently heard at its best, I think, on the whole, I should say among officers of the British Regular Army. The utterance of these men is at once clear-cut and precise, yet free from affectation; at once downright and manly, yet in the highest degree refined and urbane. [1934:614]

Conversely, Wyld's scathing comments on the leveled accents of English cities (somewhat misleadingly described as "Modified Standards") highlight the distinction between a leveled variety (imagined in the United States as standard) and an institutionalized class accent defined by a set of prescriptive norms. For Wyld, leveled varieties are simply unacceptable:

It is urged however, that to introduce provincial sounds into what is intended to beStandard English, addressed to educated people, is distressing and distracting. For the various forms of Modified Standard of towns which reflect class influence, and are of the nature of plain vulgarisms, there is little to be said except in dispraise. [1934:613-614]

In an article written in 1951 and published in 1965, the phonetician David Abercrombie writes of the use of RP as a class indicator and of discrimination against those who did not speak it. He deliberately highlights the parallel between class discrimination and racial discrimination:

It is not easy to put into words how this accent-bar works. Your social life or your career or both may be affected by whether you possess it [RP] or do not ... I be lieve it is not putting it too strongly to say that in all occupations for which an educated person is required, it is an advantage to speak RP, and it may be a disadvantage not to speak it. ... In England standard English speakers are divided by an "accent-bar," on one side of which is RP, and on the other side all the other accents. And very often the first judgment made on a stranger's speech is the answer to the question: which side of the accent bar is he? ... The accent bar is like the colour bar-to many people on the right side of the bar it appears eminently reasonable. [1965:13-14]

Still later, Edwards (1983:217) draws attention to a letter written in 1974 to John Stevens, the son of a London docker and a highly competent student teacher. The letter explicitly rejected him as a suitable candidate as a lecturer 
in a teachers' training college purely because of his spoken language. All this suggests a considerable incentive for speakers to change local accents, and in the 20th century the BBC provided a model for those who wished to do so. Only in the 1960s was the policy of insisting on RP speakers on radio and television abandoned, and at about the same time the requirement of a prescribed and relatively homogeneous accent became relaxed also in the public schools and the Anglican church.

Some consideration of class relations in Britain, particularly in England, helps explain why contemporary British language ideology stigmatizes particularly severely the dialects of major industrial cities such as Liverpool and Birmingham, even, as is clear from Wyld's comments, the leveled varieties spoken by educated groups. Crowley (1989:209-215) notes that, at the beginning of the 20th century, class conflict became much more overtly bitter than before, to the extent that industrial relations were in effect a running class war. The English urban proletariat was viewed as a threat to social order and was described in such terms as "barbarians at our gates," "a menace to the future," "emerging like rats from a drain," "a weird and uncanny people." Class conflict became institutionalized as the trade union movement gathered strength in the early 20th century.

As spoken language became closely linked with class following the emergence of the RP accent requirement, an intense awareness of class-based linguistic differences appears to have been fed by these hostile class relations. Crowley quotes the opinion of the author John Galsworthy that "there is perhaps no greater divide in society than the differences in viva-voce expression" (1924:8). The author C. H. Rolph (b. 1901) rose from modest employment as a clerk in a clothing firm to become a London police inspector and writer for the high quality journal the New Statesman. In terms that give some idea of the size of Galsworthy's "divide in society," he describes in his memoirs his reaction at the age of 17 to hearing the voice of a young woman whom he had for some time admired from afar:

[She had] the period voice of the East End Cockney, ugly and abrasive. Having heard her speak, and registered to my secret rage that she should have been saddled for life with this ugliest of all versions of my native tongue, I immediately lost interest in her as a girl, and now recall her merely as a method of producing unpleasant noises. [Rolph 1987, cited in Honey 1989:35]

Such evidence suggests that in Britain, in the 19th and well into the 20th century, the kind of visceral reactions described by Woolard are indeed reserved for language varieties that index stigmatized social classes. The ideological discourse developed then still underlies the prestige ranking assigned to British accents.

\section{The United States: Some Historical Issues}

Before the late 19th century, national multilingualism and personal bilingualism were generally accepted in the United States as facts of life. French was spoken in the eastern areas formerly held and populated by the French and is still spoken in parts of the Northeast (particularly Maine) and the 
South. Louisiana published its statutes in French between 1805 and 1850, and Pennsylvania in German from 1805 to 1850. The large German population of the United States has a particularly long history of effective mother tongue maintenance, as noted by Benjamin Rush:

What Pennsylvanian of British or Irish extraction would not prefer German [German speakers] as fellow citizens learned in the arts and sciences than in a state of ignorance of them all? A man who is learned in the dialect of a Mohawk Indian is more fit for a legislator than a man who is ignorant even in the language of the early Greeks. The German language has existed for fifty years in Pennsylvania. It never can be lost while German churches and schools exist in it. A German college will serve to preserve it, but it will preserve it, not in its present state, but in its original force and purity. [1951:365-366, quoted in Heath 1992:23]

It was only American participation in World War I that wiped out the German-language school system, which operated in 26 out of 45 states, along with German-language newspapers and a range of language-maintaining social and cultural centers (Bourhis and Marshall 1999).

At the time of the founding of the new republic, the pragmatic 18thcentury desire expressed by Rush to spread learning regardless of the learner's native tongue was widely accepted. Some thinkers such as John Adams and Noah Webster promoted English as a national language although it was apparently not yet ideologized as an index of national loyalty and American values. Nevertheless, Benjamin Franklin (1992, originally published in 1753) provides an early example of an Anglocentric discourse comparable to that of the late-20th-century English Only movement.

Complaining about the Pennsylvanian Germans' large numbers ("they come in droves"), their success in maintaining their mother tongue ("few of their children learn English"), and their general uncouthness ("those who come hither are generally the most ignorant and stupid Sort of their own nation"), he fears that these apparently inassimilable speakers will create cultural and political anarchy: "They will soon so outnumber us, that all the advantages we have will not, in My Opinion, be able to preserve our language, and even our government will become precarious" (Crawford 1992:19).

The class distinctions noted as salient in Britain differ from those in the industrial north of the United States in a manner consistent with contrasts in national language ideologies. According to Rogers and Wilenz (1991), terminology such as labor, capital, working class, and middle class became less common as successive waves of immigrants from Europe and Southern black migrants to northern cities formed a new hierarchy, each new wave occupying the lowest position. Evaluatively loaded names for ethnic categories proliferated (such as "Slav," "Teuton," "Paddy," "Dago," "Polack"), and a taxonomy of race developed parallel to the elaborate British taxonomy of class described by Mugglestone. In short, racial and ethnic categories appear to have been foregrounded, with class occupying a less salient position in American cultural models as the United States developed into an industrial nation. Contrasts between national schemata are highlighted by the American analogue to Booth's (1892) classic work. Booth surveyed work- 
ing-class London using a set of class taxonomies, half above and half below the poverty line. In 1907 the Russell Sage Foundation carried out a survey of Pittsburgh modeled on Booth but gave up any attempt to impose his categories, settling instead for a number of "racial studies." Only when free immigration ended in the 1920s did the Census Bureau follow the English model of expressing inequality in terms of a careful gradation of classes (Marwick 1980; Rogers and Wilenz 1991:249). Goldschmidt (1999) offers an analysis of the dynamics of status in contemporary America consistent with a focus on ethnicity, whereby particular ethnic groups move up from the most impoverished position as their place is taken by more recent immigrants.

The group seen as a threat to the social fabric of the United States in the early 20th century thus seems to be immigrants, often speaking languages other than English-not, as in Britain, an urban proletariat speaking varieties of English rooted in historically established dialects. Theodore Roosevelt's call for homogeneity and Anglo-conformity resembles the discourse of the late-20th-century ELA movement: "We have room but for one language here and that is the English language, for we intend to see that the crucible turns our people out as Americans, of American nationality, and not as dwellers in a polyglot boarding house" (Roosevelt, cited in Crawford 1992:100).

Comparing the contemporary English Only movement to the early-20th-century Americanization Campaign, Leibowicz remarks that at times of heavy immigration bilingualism becomes a salient political issue in the United States. Thus, at the turn of the century and currently, the pendulum has swung away from a movement to cultural pluralism toward Anglo-conformity:

Where the Americanizers were afraid of Slavic or Mediterranean hordes, supporters of ELA are afraid of Spanish and the people who speak it. It's almost as if we had traveled back in time seventy-five years; once again the United States is facing unprecedented numbers of non-English speakers, seemingly unassailable, and possibly hostile to American ideals and institutions. [Leibowicz 1992:109-110]

While the turn-of-the-century peak in immigration appears to be a historical event influential in shaping a characteristically American language ideology, other 19th-century developments also encouraged a less tolerant view of multilingualism. As the West was opened up, the Gold Rush attracted a wave of Chinese immigrants who experienced exceptional discrimination (Wong 1988). The annexation in 1848 of the Mexican territories of the Southwest forced under American rule 75,000 Spanish-speaking people who had been established in the region since the mid-16th century. The Treaty of Hidalgo was intended to protect their political, civil, religious, cultural, and linguistic rights, but a massive increase in the English-speaking population created a Spanish-speaking minority and transformed the lifestyle of the region. The resultant cultural conflict produced a series of laws that discriminated against Mexican American language and culture and affects Mexican Americans to this day. Particularly, California became in 1878 the first English Only state; official proceedings were restricted to English and guarantees for Spanish-language publications agreed to at the treaty of Hidalgo were eliminated. 
The conquest of the West turned Native Americans also into linguistic minorities subject to language-based discrimination. The following is an extract from the 1887 annual report of the commissioner for Indian affairs, J. D. C. Atkins:

Schools should be established which children should be required to attend; their barbarous dialects should be blotted out and the English language substituted.... [T]he object of greatest solicitude should be to break down the prejudices of tribe among the Indians; to blot out the boundary lines which divide them into distinct nations, and fuse them into one homogeneous mass. Uniformity of language will do this. Nothing else will.... It is also believed that teaching an Indian youth in his own barbarous dialect is a positive detriment to him. The first step to be taken towards civilization, towards teaching the Indians the mischief and folly of continuing in their barbarous practices is to teach them the English language. [1887, cited in Crawford 1992:48-51]

The cruel policy recommended here was energetically pursued, with the disastrous effect that after years at school children could neither find employment and assimilate to the white mainstream nor find a place in their home communities. Thus, Crawford (1992:323) notes, in the late 19th century not only the Spanish-speaking population of the Southwest but also the indigenous population of a previously multilingual United States became victims of a severe and subtle form of discrimination that set them up not only for an invidious sense of inferiority about their own language and culture but for educational failure and disadvantage in the employment market. By Atkins's time English had become ideologized so that English monolingualism was imagined, iconically, to be an essential component of democratic American ideals and generally proper and civilized behavior. The same perception of English as an ideological cornerstone is evident in many of the 19th- and 20th-century readings in Crawford 1992.

The stigmatization of African American English in the United States is fairly uncontroversially associated with attitudes deriving from colonial history and institutionalized racial slavery. Events in the United States subsequent to abolition that bear on the ideological construction of AAE are too complex to document here- but see Johnson et al. 1998 and references therein for comprehensive discussions of issues arising from the enforced presence of Africans in the United States. These include the Civil War and its aftermath, conflicts between settlers moving west who wanted to establish slave states and those who did not, a long-standing reluctance to grant African Americans full civil rights, white hostility to free black communities both before and after abolition, a deep-seated fear of violence and rebellion felt by the white community, and white perceptions of African American migrants to the northern cities as unfair competition in the labor market. Johnson et al. document a long-standing racist perception in the United States of Africans as intrinsically less than human, a group that the state was not obliged to accommodate as citizens on the same basis as those categorized as "white." They also discuss the emergence of a cultural model that dichotomized the early colonial population in this way (1998:39-40). 


\section{Discussion and Conclusion}

In this concluding section, I shall attempt to pull together strands of the argument developed in preceding sections, noting implications that arise from the comparative analysis of language ideologies presented there. The central claim is that language varieties in Britain and America are differently ideologized so as to foreground social class groups in Britain and racial or ethnic groups in the United States. The argument was supported by a range of discourse samples taken from print and television media and from discussions of language-related policy issues. Distinctive ideologies are manifested rather dramatically in British and American language controversies, which are equally salient and politically contentious in both countries.

In both countries the standard is ideologized as a neutral reference point for all descriptions of variation. Also in both countries a belief in a single correct form of the language figures prominently in popular cultural models. But here commonalties end, and sharply different images of the standard emerge as central to the structure of distinctive ideological systems in a way that is not immediately obvious. In the United States, the spoken standard is imagined as a mainstream leveled variety, shorn of those ideologized grammatical and lexical forms that index social, regional, or ethnic groups. Moreover, phonology seems to be relatively unimportant in defining standardness. This image of a leveled standard is consistent with the emergence of relatively homogenized contact varieties in the colonial period and with early American ideals that found aristocratic standards of the kind associated with the Old World unacceptable.

Such an image of the standard as "mainstream" has the effect of erasing social class as a salient element in American language ideology, since mainstream codes are by definition spoken not by an elite but by a wide range of speakers; so much is recognized in contemporary accounts such as that of Wolfram and Schilling-Estes (1998). But the mainstream image entails also the construction of nonmainstream elements in the ideological system, so that codes indexing socially stigmatized speakers are imagined as peripheral. The language varieties of disfavored ethnic minority groups are saliently foregrounded in this position in the ideological system, and those spoken by southerners, defeated in a divisive conflict with those who view themselves as mainstream, are also imagined as peripheral. The American ideological system thus provides for such negative attitudes toward Southern English as those noted by Preston (1996) and Lippi-Green (1997).

The mainstream/peripheral dichotomy appears to be central to a larger social domain than constructs of linguistic (non)standardness. Schmidt (1993) observes that acceptance of ethnic and linguistic diversity would entail a reconstruction of American mainstream identity, in that European Americans would no longer constitute the reference point for "Americanness" but would be one (or several) ethnic group(s) among many. Similarly, the construction of standard American English as mainstream can be interpreted as a strategy for preserving the right of this group to identify themselves not only as a national reference point but more specifically as a linguistic reference point for American English. 
The standard language in Britain is ideologized very differently. There, phonology-popularly described as "accent"-is critical in images of the "best English"; Received Pronunciation, a class-marked accent associated historically with educated or aristocratic speakers in the south of England, is treated as a central reference point but is imagined as elite rather than mainstream. Since RP explicitly indexes upper- and upper-middle-class groups, the varieties that are particularly stigmatized and disfavored are correspondingly constructed with reference to class-hence the particular stigma attached to varieties spoken in industrial cities, which are historically associated with working-class speakers. Ethnic varieties such as London Jamaican are also stigmatized but, unlike African American English in the United States, do not appear to occupy a particularly disparaged position. The "mainstream" standard in the United States and the "class-marked" standard in Britain thus occupy critical positions as central reference points in the two systems. Each sets up a pattern of structural oppositions that foregrounds and stigmatizes those codes that index "nonmainstream" groups in the United States and "lower-class" groups in Britain.

Following Irvine and Gal's (1994) observation that events, activities, and people experienced as significant are likely to influence the construction of particular language ideologies, it was suggested that developments in both Britain and the United States in the 19th and early 20th centuries were helpful in accounting for the contrasting structures of British and American language ideologies. In the United States, heavy immigration in the late 19th century, along with events associated with the conquest of the West, emerge as input to a language ideology that constructs the language codes of speakers of languages other than English as peripheral. During the late 19th and early 20 th centuries in Britain, working-class people in industrial cities became particularly stigmatized during a period of fierce class conflict, apparently occupying a position in the ideological system corresponding to that of the immigrants in the United States. The concurrent emergence of accent as an index of class in 19th-century Britain is well documented, as is the emergence of a discourse of class that makes fine phonological distinctions between speakers. During the same period, RP was codified and explicitly taught in the public schools, so that an "accent bar" developed in Britain that was socially salient well into this century. These developments, which appear to have no clear analogue in the United States, help to account not only for the salience of class in British language ideologies but for the prominence of accent (as opposed to grammar and lexis) in British images of the standard.

George Bernard Shaw has described Britain and the United States as two nations divided by the same language. By this he presumably meant that possession of a common language was a faux ami, lulling cross-Atlantic conversationalists into the false assumption of a common culture and common grammar, lexis, and communicative conventions. By the same token, the possession of a common language may submerge salient differences in language ideology that present a less tangible challenge to cross-Atlantic communication but are deeply embedded culturally, cognitively, and historically. 


\section{Notes}

Acknowledgments. My thanks go to the following for helpful comments on earlier drafts: Anthony Berkeley, Alaina Lemmon, Rosina Lippi-Green, Jim Milroy, and Kathryn Woolard. Remaining defects are, of course, my responsibility. Particular thanks go to Judy Irvine, whose insightful comments went far beyond the call of editorial duty.

1. I have argued elsewhere that this formulation is problematic and that a standard language is best described in terms of a process that affects some linguistic levels more readily than others; phonology is simply the level most resistant to standardization (see further Milroy and Milroy 1998).

2. The association between the aristocracy and the emergent spoken prestige form documented by Puttenham and others needs to be interpreted with care. From the time of the emergence of the so-called Chancery Standard in the 15th century-effectively a leveled variety developed and used by lawyers-upper-class forms have been replaced by middle-class innovations as spoken and written Standard English has evolved.

3. I am grateful to Judy Dyer for drawing my attention to this article.

4. Both Rickford (1999) and Cameron (1995) comment on the frustration (and ultimate wrongheadedness) of sociolinguists who attempt to counter palpably false linguistic beliefs but do not attend to underlying (nonlinguistic) ideological constructs.

5. I am indebted to Keith Walters for his discussion of these extracts (Walters 1996).

6. At that time in Liverpool a Lancashire dialect was spoken, antedating mass Irish migration to Liverpool and subsequent emergence of the modern Anglo-Irish contact dialect known as "Scouse."

\section{References Cited}

\section{Abercrombie, David}

1965 Studies in Linguistics and Phonetics. Oxford: Oxford University Press. Ascherson, Neal

1994 Britain's Crumbling Ruling Class Is Losing the Accent of Authority. Independent. Sunday, August 7.

Atkins, J. D. C.

1992[1887] Barbarous Dialects Should Be Blotted Out. In Language Loyalties: A

Sourcebook on the Official English Controversy. James Crawford, ed. Pp. 47-50. Chicago: University of Chicago Press.

Barker, Pat

1993 The Eye in the Door. The Regeneration Trilogy, bk. 1. London: Allen Lane. Baugh, John

1996 Linguistic Discrimination. In Contact Linguistics: A Handbook of Contem-

porary Research. Hans Goebl, Peter Nelde, et al., eds. Pp. 709-714. Berlin: de Gruyter.

Booth, Charles

1892 Life and Labor of the People of London. London: Macmillan. Bourhis, Richard Y., and David F. Marshall

1999 The United States and Canada. In Handbook of Language and Ethnic Identity. Joshua Fishman, ed. Pp. 244-264. Oxford: Oxford University Press. 
Cameron, Deborah

1995 Verbal Hygiene. London: Routledge.

Cárdenas, José A.

1992 An Educator's Rationale for Native Language Instruction. In Language

Loyalties: A Sourcebook on the Official English Controversy. James Crawford, ed. Pp. 342-351. Chicago: University of Chicago Press.

Carter, Ronald

1999 Standard Grammars, Spoken Grammars: Some Educational Implications.

In Standard English: The Widening Debate. Tony Bex and Richard J. Watts, eds.

Pp. 149-167. London: Routledge.

Castro, Max

1992 On the Curious Question of Language in Miami. In Language Loyalties: A Sourcebook on the Official English Controversy. James Crawford, ed. Pp. 178-185. Chicago: University of Chicago Press.

Chambers, Jack K.

1995 Sociolinguistic Theory. Oxford: Blackwell.

Cheshire, Jenny, and James Milroy

1993 Syntactic Variation in Non-Standard Dialects: Background Issues. In Real

English: The Grammar of English Dialects in the British Isles. James Milroy and

Lesley Milroy, eds. Pp. 3-33. London: Longman.

Coggle, Paul

1993 Between Cockney and the Queen. Wordpower Supplement, Sunday Times

(London), March 28:21-24.

Corfield, Penelope J.

1991 Language, History and Class. Oxford: Blackwell.

Crawford, James, ed.

1992 Language Loyalties: A Sourcebook on the Official English Controversy.

Chicago: University of Chicago Press.

Crowley, Tony

1989 Standard English and the Politics of Language. Urbana: University of Illinois Press.

D'Andrade, Roy

1987 A Folk Model of the Mind. In Cultural Models in Language and Thought.

Dorothy Holland and Naomi Quinn, eds. Pp. 112-148. Cambridge: Cambridge

University Press.

Daubney, Martin

1996 Can Your Accent Blight Your Life? Bella, January 24:23.

Dorling, Daniel

1995 A New Social Atlas of Britain. New York: Wiley.

Eagleton, Terence

1991 Ideology: An Introduction. London: Verso.

Edwards, Viv

1983 The Grammar of Southern British English. In Real English: The Grammar of

English Dialects in the British Isles. James Milroy and Lesley Milroy, eds. Pp.

214-238. London: Longman.

Fairclough, Norman

1992 The Appropriacy of "Appropriateness." In Critical Language Awareness.

Norman Fairclough, ed. Pp. 33-56. London: Longman. 
Fishman, Joshua

1992[1988] The Displaced Anxiety of Anglo Americans. In Language Loyalties:

A Sourcebook on the Official English Controversy. James Crawford, ed. Pp. 165-170. Chicago: University of Chicago Press.

Franklin, Benjamin

1992[1753] The German Language in Pennsylvania. In Language Loyalties: A

Sourcebook on the Official English Controversy. James Crawford, ed. Pp.

18-19. Chicago: University of Chicago Press.

Galsworthy, John

1924 On Expression. English Association, pamphlet 59. Oxford.

Giddens, Anthony

1989 Sociology. London: Polity.

Giles, Howard, and Nikolas Coupland

1991 Language: Contexts and Consequences. Milton Keynes: Open University

Press.

Giles, Howard, and Peter F. Powesland

1975 Speech Style and Social Evaluation. New York: Academic Press.

Goldschmidt, Walter

1999 Dynamics of Status in America. Anthropology News 40(5):62-64.

Heath, Shirley B.

1992 Why No Official Tongue? In Language Loyalties: A Sourcebook on the Of-

ficial English Controversy. James Crawford, ed. Pp. 20-30. Chicago: University of Chicago Press.

Heller, Monica

1995 Codeswitching and the Politics of Language. In One Speaker, Two Languages: Cross-Disciplinary Perspectives on Bilingualism. Lesley Milroy and Pieter Muysken, eds. Pp. 90-112. Cambridge: Cambridge University Press.

Herman, Edward, and Noam Chomsky

1988 Manufacturing Consent: The Political Economy of the Mass Media. New York: Pantheon.

Honey, John

1989 Does Accent Matter? London: Faber.

Irvine, Judith T., and Susan Gal

1994 Language Ideology and Linguistic Differentiation. Paper presented at the Seminar on Language Ideologies, School of American Research, Santa Fe, NM. (2000 in Regimes of Language, Paul Kroskrity, ed., Santa Fe, NM: School of American Research Press.)

Johnson, Charles, Patricia Smith, and the WGBH Research Team

1997 Africans in America: America's Journey through Slavery. New York: Harcourt Brace and Co.

Jones, Daniel

1917 English Pronouncing Dictionary. London: Longman.

Kerswill, Paul

1996 Children, Adolescents and Language Change. Language Variation and Change 8(1):177-202.

Labov, William

1972a[1969] The Logic of Non-Standard English. In Language and Social Context. Piers Paul Giglioli, ed. Pp. 283-307. Harmondsworth, UK: Penguin.

1972b Sociolinguistic Patterns. Philadelphia: University of Pennsylvania Press. 
Lambert, Wallace E.

1960 Evaluational Reactions to Spoken Languages. Journal of Abnormal and Social Psychology 60:44-51.

Leibowicz, Joseph

1992[1985] Official English: Another Americanization Campaign? In Language Loyalties: A Sourcebook on the Official English Controversy. James Crawford, ed. Pp. 101-111. Chicago: University of Chicago Press.

Lippi-Green, Rosina

1997 English with an Accent: Language, Ideology and Discrimination in the United States. London: Routledge.

Macaulay, Ronald

1977 Language and Social Class in Glasgow. Edinburgh: University of Edinburgh Press.

Marwick, Arthur

1980 Class: Image and Reality in Britain, France and the USA since 1930. Oxford: Oxford University Press.

McArthur, Tom

1986 Comment: Worried about Something Else. International Journal of the Sociology of Language 60:87-91.

Mencken, Henry Louis

1945 The American Language, suppl. 1. New York: Knopf.

Milroy, James, and Lesley Milroy

1998 Authority in Language. 3rd edition. London: Routledge.

Milroy, Lesley

In press The Social Categories of Race and Class: Language Ideology and Sociolinguistics. In Sociolinguistics and Social Theory. Nikolas Coupland, Srikant Sarangi, and Chris Candlin, eds. London: Longman.

Milroy, Lesley, and Paul McClenaghan

1977 Stereotyped Reactions to Four Educated Accents in Ulster. Belfast Working Papers in Language and Linguistics 2, paper 4. Department of Linguistics, Ulster Polytechnic. Mimeographed.

Milroy, Lesley, and James Milroy

1992 Social Network and Social Class: Towards an Integrated Sociolinguistic Model. Language in Society 21(1):1-26.

Montgomery, Michael

1996 Was Colonial American English a Koiné? In Speech Past and Present: Essays in Honour of Ossi Ihilainen. Juhani Klemola, Merja Kyto, and Matti Rissanen, eds. Pp. 213-235. Frankfurt: Peter Lang.

Mugglestone, Linda

1995 Talking Proper: The Rise of Accent as a Social Symbol. Oxford: Clarendon. Newbolt, Henry

1921 The Teaching of English in England. London: HMSO.

Niedzielski, Nancy, and Dennis R. Preston

1999 Folk Linguistics. Berlin: Mouton de Gruyter.

Oliphant, Thomas K.

1873 The Sources of Standard English. London: Macmillan.

Preston, Dennis

1996a Where the Worst English Is Spoken. In Focus on the USA. Edgar W.

Schneider, ed. Pp. 297-361. Amsterdam: Benjamins. 
1996b "Whaddayaknow": The Modes of Folk Linguistic Awareness. Language Awareness 5(1):40-74.

N.d. Folk Metalanguage. Unpublished MS.

Proulx, Annie

1997 Accordion Crimes. London: Fourth Estate.

Puttenham, George

1936[1589] The Arte of English Poesie. Gladys D. Willcock and Alice Walker, eds. Cambridge: Cambridge University Press.

Read, Allen Walker

1980 British Recognition of American Speech in the Eighteenth Century. In Perspectives on American English. J. L. Dillard, ed. Pp. 15-36. The Hague: Mouton. Originally published in Dialect Notes 6.

Rickford, John R.

1999 The Ebonics Controversy in My Backyard: A Sociolinguist's Experiences and Reflections. Journal of Sociolinguistics 3(2):267-275.

Roberts, Celia, Evelyn Davies, and Tom Jupp

1992 Language and Discrimination: A Study of Communication in Multi-Ethnic

Workplaces. London: Longman.

Rogers, Daniel T., and Sean Wilenz

1991 Languages of Power in the United States. In Language, History and Class.

Penelope J. Corfield, ed. Pp. 240-263. Oxford: Blackwell.

Rolph, Cecil H.

1987 Further Particulars. Oxford: Oxford University Press.

Rumsey, Alan

1990 Wording, Meaning and Linguistic Ideology. American Anthropologist 92: 346-361.

Rush, Benjamin

1951 Letters. Princeton: Princeton University Press for the American Philosophical Association.

Schmidt, Richard

1993 Language Policy Conflict in the United States. In The Rising Tide of Cultural Pluralism: The Nation State at Bay? Carl Young, ed. Pp. 73-92. Madison: University of Wisconsin Press.

Sebba, Mark

1993 London Jamaican. London: Longman.

Silverstein, Michael

1992 The Uses and Utility of Ideology: Some Reflections. Pragmatics 2(3): 311-323.

1995 Indexical Order and the Dialectics of Social Life. In Proceedings of the Third Annual Symposium about Language and Society-Austin. Risako Ide, Rebecca Parker, and Yukako Sunaoshi, eds. Pp. 266-295. Austin: University of Texas Department of Linguistics.

Simon, John

1980 Paradigms Lost: Reflections on Literacy and Its Decline. Harmondsworth, UK: Penguin.

Smith, Jeremy

1996 An Historical Study of English: Function, Form and Change. London: Routledge. 


\section{Smith, Joe}

1997 Employers Admit That They Still Lend an Ear to Accents. Times (London), January 2:6.

Standard and Black English

1987 Oprah Winfrey Show. WLS-TV, Chicago. November 19. Transcript.

Tory, Peter

1994 Pity the Young Who Converse Only in Oik. International Express, August 7:24.

Trask, R. Larry

1996 Historical Linguistics. London: Arnold.

Trudgill, Peter

1999 Standard English: What It Isn't. In Standard English: The Widening Debate.

Tony Bex and Richard J. Watts, eds. Pp. 117-128. London: Routledge.

Walters, Keith

1995 Contesting Representations of African American Language. In Proceedings of the Third Annual Symposium about Language and Society-Austin. Risako Ide, Rebecca Parker, and Yukako Sunaoshi, eds. Pp. 137-151. Austin: University of Texas Department of Linguistics.

Waterhouse, Keith

1994 Speaking As We Find. Daily Mail, August 4:10.

West, Cornel

1993 Race Matters. Boston: Beacon.

Wolfram, Walt

1991 Dialects and American English. Washington, DC: Center for Applied Linguistics.

1999 Review of English with an Accent. Language 75(2):362-365.

Wolfram, Walt, and Natalie Schilling-Estes

1998 American English. Oxford: Blackwell.

Wong, Sau-Ling Cynthia

1988 The Language Situation of Chinese Americans. In Language Diversity:

Problem or Resource? Sandra Lee McKay and Sau-Ling Cynthia Wong, eds. Pp. 193-228. Boston: Heinle and Heinle.

Woolard, Kathryn A.

1989 Double Talk. Stanford: Stanford University Press.

1992 Language Ideologies: Issues and Approaches. Pragmatics 2(3):235-249.

Woolard, Kathryn A., and Bambi Schieffelin

1994 Language Ideology. Annual Review of Anthropology 23:55-82.

Wyld, Henry Cecil

1934 The Best English: A Claim for the Superiority of Received Standard English. Society for Pure English 4(tract 39):603-621.

Department of Linguistics

University of Michigan

1080 Frieze Hall

Ann Arbor, MI 48109

amilroy@umich.edu 